\title{
Growth of Cultured White Leg Shrimp Litopenaeus Vannamei (Boone, 1931) of Brackish Water Culture System in Winter Season with Artificial Diet
}

\section{Jagadish Naik Mude ${ }^{1 *}$ and Danya Babu Ravuru ${ }^{2}$}

${ }^{1}$ Assistant Professor, Department of Zoology and Aquaculture, Acharya Nagarjuna University, Guntur, Andhra Pradesh-522510, India

${ }^{2}$ Department of Zoology and Aquaculture, Acharya Nagarjuna University, Guntur, Andhra Pradesh-522510, India

\begin{abstract}
The White leg shrimp Litopenaeus vannamei culture was conducted from three ponds each one of 0.5 ha for the study. Semi-Intensive culture system was selected under brackish water conditions. Stocking densities (post larvae) were taken from 3 samples; each one contains 50 Numbers $/ \mathrm{m}^{2}$. In winter season in month of November to February, the water quality parameters were measured fortnightly in a month at $7 \mathrm{a} . \mathrm{m}$. The production was 3200,3318 and $3459 \mathrm{~kg}$ and FCR was $1.43,1.51$ and 1.46 and the final growth was $16.50,17.00$ and $17.50 \mathrm{~g} / 90,92$ and 94 days for P1, P2 and P3, respectively.
\end{abstract}

Keywords: L. vannamei; Temperature; Salinity; Density; Feed; Growth and Production

\section{Introduction}

Because of the high demand for shrimps in Japan, the United States and Europe, shrimp aquaculture has expanded rapidly in all around the world, especially in tropical areas, such as Southeast Asia and Latin America [1]. Among all species of shrimp, L. vannamei, which represent over $90 \%$ of shrimp culture in the Western hemisphere, is the most commonly cultured shrimp in Central and South American countries, China, and Thailand [2-4]. India has the one of the longest line of $8118 \mathrm{~km}$.

\section{Material and Methods}

The shrimp 15 days old post larvae L.vannamei at beginning the study collected from BMR hatchery. The winter season experiments the species L.vannamei survival were 82,84 and $86 \%$, respectively. Water depth maintained $8 \mathrm{ft}$. The water takes from creek pumped to 3 ponds by PVC pipe (size $2 \frac{1}{2}$ inch). The $\mathrm{PH}$, temperature, salinity and $\mathrm{DO}$ ranges up to $7.0-8.2,13.0-16.5^{\circ} \mathrm{C}, 6.0-12.5 \mathrm{ppt}$ and $3.4-4.2 \mathrm{ppm} /$ day for P1, P2 and P3. The artificial diet was given made by Manamei feed (protein\% 35 (Feed No. 1, 2, 3 and 3S) and 34(Feed No. 3M)).

\section{Results}

In the experiment the water quality parameters are presented (Table 1). The species L.vannamei well grow, the body weight increased 3.0-3.5 $\mathrm{g}$ and ADG $0.18 \mathrm{~g}$ (P1, P2 and P3) 15 days in Indian climate conditions, which is better than other countries. In the culture system the growth rate increased due to the artificial feed supplementation in the season. The mean average weights of the shrimp at harvest were $16.5,17.0$ and $17.5 \mathrm{~g}$ (Tables 2, 3 and 4) and production was 3200, 3318 and $3459 \mathrm{~kg}$ and FCR was 1.36, 1.40 and 1.46/90, 92 and 94 for P1, P2 and $\mathrm{P} 3$, respectively.

\section{Discussion}

A large number of shrimp could be assembled on the aquaria bottom from the artificial substrates [5]. Many studies have illustrated that artificial substrates could increase shrimp growth and survival [6,7]. Abiotic factors such as temperature and salinity may also affect the protein requirement [8]. "Booster" mineral is given to 3 ponds depending on biomass for development the minerals. "Opti oxygen" controls the DO. "AQ lite" for bottom clears. The shrimp maintained at $35^{\circ} \mathrm{C}$ had the highest rate of food consumption Arenda et al. [9] recorded the average growth rate of $0.38 \mathrm{~g} / \mathrm{wk}$ in the $90 \mathrm{shrimp} /$ $\mathrm{m}^{2}$ and lowest in the $180 \mathrm{shrimp} / \mathrm{m}^{2}(0.33 \mathrm{~g} / \mathrm{wk})$. My observation at $7-8.2^{\circ} \mathrm{C}$ the shrimp highest growth rate $4 \mathrm{~g} /$ fortnightly $\left(50 \mathrm{shrimp} / \mathrm{m}^{2}\right)$ and lowest growth $3.5 \mathrm{~g} /$ fortnightly $\left(50 \mathrm{shrimp} / \mathrm{m}^{2}\right) / 94$ and 92 days.

\begin{tabular}{|c|c|c|c|}
\hline Parameters & P1 range & P2 range & P3 range \\
\hline $\mathbf{P}^{\mathrm{H}}$ & $7.0-7.5$ & & $7.5-8.2$ \\
\hline Temperature $\left(^{\circ} \mathbf{C}\right)$ & $13.0-16.0$ & & $13.5-16.5$ \\
\hline Salinity $(\mathbf{p p t})$ & $6.0-12.0$ & $6.0-12.5$ & $6.5-12.5$ \\
\hline DO $(\mathbf{p p m})$ & $3.4-4.0$ & $3.5-4.0$ & $3.5-4.2$ \\
\hline
\end{tabular}

Table 1: Average water quality parameters

\begin{tabular}{|c|c|c|c|c|c|c|}
\hline Pond & & & & & \\
\hline & 15 & 30 & 45 & 60 & 75 & 90 \\
\hline P1 & 2.00 & 4.00 & 7.00 & 10.00 & 13.00 & 16.50 \\
\hline \multicolumn{7}{|c|}{ Table 2: Fortnightly growth performance (g) } \\
\hline
\end{tabular}

\begin{tabular}{|c|c|c|c|c|c|c|}
\hline Pond & & \multicolumn{3}{|c|}{} & & \\
\hline & 15 & 30 & 45 & 60 & 75 & 92 \\
\hline P2 & 2.00 & 4.50 & 7.50 & 10.50 & 13.50 & 17.00 \\
\hline
\end{tabular}

Table 3: Fortnightly growth performance (g)

\begin{tabular}{|l|c|c|c|c|c|c|}
\hline Pond & & \multicolumn{3}{|c|}{} & \\
\hline & 15 & 30 & 45 & 60 & 75 & 94 \\
\hline P2 & 2.00 & 4.50 & 7.50 & 10.50 & 13.50 & 17.50 \\
\hline \multicolumn{7}{|c|}{ Table 4: Fortnightly growth performance (g) } \\
\hline
\end{tabular}

*Corresponding author: Jagadish Naik Mude, Assistant Professor, Department of Zoology and Aquaculture, Acharya Nagarjuna University, Guntur, Andhra Pradesh-522510, India, Tel: 9948120530; E-mail: jagadish100 naik@gamil.com

Received November 03, 2014; Accepted December 18, 2014; Published January 20, 2015

Citation: Mude JN, Ravuru DB (2015) Growth of Cultured White Leg Shrimp Litopenaeus Vannamei (Boone, 1931) of Brackish Water Culture System in Winter Season with Artificial Diet. J Aquac Res Development 6: 304 doi:10.4172/21559546.1000304

Copyright: (C) 2015 Mude JN, et al. This is an open-access article distributed under the terms of the Creative Commons Attribution License, which permits unrestricted use, distribution, and reproduction in any medium, provided the original author and source are credited. 
Citation: Mude JN, Ravuru DB (2015) Growth of Cultured White Leg Shrimp Litopenaeus Vannamei (Boone, 1931) of Brackish Water Culture System in Winter Season with Artificial Diet. J Aquac Res Development 6: 304. doi:10.4172/21559546.1000304

Page 2 of 2

\begin{tabular}{|l|c|c|c|}
\hline Details & Pond 1 & Pond 2 & Pond 3 \\
\hline Area (ha) & 0.5 & 0.5 & 0.5 \\
\hline Initial stocking (Numbers) & $2,50,000$ & $2,50,000$ & $2,50,000$ \\
\hline Density/m² & 50 & 50 & 50 \\
\hline Stocking Date & $02 / 11 / 2012$ & $02 / 11 / 2012$ & $02 / 11 / 2012$ \\
\hline PL stocking (Days) & $\mathrm{PL}_{15}$ & $\mathrm{PL}_{15}$ & $\mathrm{PL}_{15}$ \\
\hline Harvest Date & $02 / 02 / 2013$ & $04 / 02 / 2013$ & $06 / 02 / 2013$ \\
\hline Harvest size (gm) & 16.50 & 17.00 & 17.50 \\
\hline Count (numbers/kg) & 60.6 & 58.8 & 57.1 \\
\hline Doc & 95 & 98 & 101 \\
\hline Survival (\%) & 82 & 84 & 86 \\
\hline FCR & 1.36 & 1.40 & 1.46 \\
\hline ADG (g) & 0.18 & 0.18 & 0.18 \\
\hline Production (kg) & 3200 & 3318 & 3459 \\
\hline Total feed (kg) & 2352 & 2359.40 & 2486.70 \\
\hline Seed cost/kg shrimp & Rs 20.50 & Rs 20.50 & Rs 20.50 \\
\hline & Table 5: Average Cost Analysis & \\
\hline
\end{tabular}

Early morning Dissolved Oxygen concentration was between 3 and 5 $\mathrm{mg} 1^{-1}$; salinity was above $15 \%$ during the first week of grow out pond, which is preferable for post larvae [10-15]. In early morning I reported Dissolved Oxygen concentration was between 3.4-4.2 ppm and salinity was between 6-12.5 ppt.

For each pond cost analysis was worked out. Production cost for $1 \mathrm{~kg}$ shrimp (60.6, 58.8 and 57.1 counts) was calculated as Rs 300 , 350 and 380 . The feed cost was Rs $71.84 / \mathrm{kg}$, followed by seed cost Rs 20.50/kg. Totally feed was used 2352, 2359 and $2359 \mathrm{~kg}$. According to Danya Babu Ravuru and Jagadish Naik Mude, in summer season better production $(\mathrm{kg})$ and profit (Rs) was 8337,8932 and $9450 ; 218.34$, 243.63 and 272.66/P1, P2 and P3 for 120, 123 and 126 days and 3200, 3318 and 3459; 102, 152 and 182/ P1, P2 and P3 for 90, 92 and 94 days (Table 5).

\section{Conclusion}

In the present study, it has been observed, Temperature, Salinity, Dissolved Oxygen, Density and Survival. The shrimp L.vannamei culture is successful in brackish water and shrimp growth was increased with artificial feed.

\section{Acknowledgement}

Authors are thankful to the Farmer and Owner of the culture ponds $\mathrm{K}$. Ramana (Neeli Aqua Pvt Ltd) in Chinaganjam Village, Prakasakm District, for their encouragement and provided facilities up to harvest.

\section{References}

1. Lombardi JV, De Almeida MHL, Toledo LPR, Salee BOJ, De Paula EJ (2006) Cage Polyculture of the Pacific white shrimp Litopenaeus vannamei and the Philippines Sea weed Kappaphycusalvarezii. Aquaculture 258: 412-415.

2. Frías-Espericueta MG, Voltolina D, Osuna-López JI (2001) Acute toxicity of cadmium, mercury and lead to white leg shrimp (Litopenaeus vannamei) post larvae. Bulletin of Environmental Contamination and Toxicology 67: 580-586.

3. Mc Graw WJ, Davis DA, Teichert-Coddington D, Rouse DB (2002) Acclimation of Litopenaeus vannamei post larvae to low salinity: influence of age, salinity, endpoint and rate of salinity reduction. J World Aquacul Soc 33: 78-84.

4. Saoud IP, Davis DA, Rouse DB (2003) Suitability studies of inland well waters for Litopenaeus vannamei culture. Aquaculture 217: 373-383.

5. Zhang B, Li WH, Huang YJW, Xu RL (2010) Effects of artificial substrates on the growth, survival and spatial distribution of Litopenaeus vannamei in the intensive culture condition. Iran J Fish Sci 9: 293-304.

6. Moss SM (2004) Effects of artificial substrate and stocking density on the nursery production of Pacific White shrimp Litopenaeus vannamei. J World Aqua culture soci 35: 537-542.

7. Arnold SJ, Coman FE, Jackson CJ, Groves SA (2009) High-intensity, zero water-exchange production of juvenile tiger shrimp, Penaeus monodon: An evaluation of artificial substrates and stocking density .Aquaculture 293: 42-48.

8. Guillaume J (1997) Protein and amino acids. World Aquaculture Society, Baton Rouge, USA

9. Arenda M, Perez EP, Gasca-Leyva E (2008) White shrimp Penaeus vanname culture in fresh water 3densities; condition state based on length and weight. Aquaculture 283: 13-18.

10. Cawthorne DE, Beard T, Davenport J, Wickins J (1983) Response of juvenile Penaeus monodon Fabricius to natural and artificial sea water of low salinity. Aquaculture 32:165-174

11. Allen GL, Maguire GB (1991) Lethal levels of low dissolved oxygen and effect of short-term oxygen stress on subsequent growth of juvenile Penaeus monodon. Aquaculture 94: 27-37.

12. Garcia A, Brune DE (1991) Transport limitation of oxygen in shrimp culture pond. Aqua Eng 10: 269-279.

13. Lee DOC, Wickins JE (1992) Crustacean forming Black Well Scientific Publications. Oxford

14. Parado-Estpa EED, Llobera A, Villaluz A, Saldes R (1993) Survival and metamorphosis of Penaeus monodon Larvae at different salinity levels. Israel J Aqua 45: 3-7.

15. Danya Babu R, Jagadish Naik M (2014) Growth of cultured white of shrimp Litopenaeus vannamei (Boone 1931) of brackish water culture system in summer season with artificial diet. Adv Appl Sci Res 5: 25-28. 